ISSN 1997-5902

\title{
Spatiotemporal variations of the incidence of the fleas (Siphonaptera) on domestic small mammals in the city of Cotonou, Benin.
}

\author{
Houemenou G. ${ }^{1}$, Kassa B. ${ }^{2}$ and Libois R. ${ }^{3}$ \\ ${ }^{1}$ Laboratoire de Biologie Appliquée, École Polytechnique d'Abomey-Calavi, Université d'Abomey-Calavi, 01BP 2009 \\ Cotonou, Bénin. \\ 2Faculté des Sciences Agronomiques, Université d'Abomey-Calavi, 01BP 526 Cotonou, Bénin \\ 3Unité de Recherche en Zoogéographie, Université de Liège, Bâtiment B22 Boulevard du Rectorat, 4031 Sart Tilman, \\ Belgium \\ Correspondence should be addressed to G. Houemenou: gualbert.houemenou@gmail.com
}

Original submitted in on 20th May 2014. Published online at www.m.elewa.org on $31^{\text {st }}$ August 2014. http://dx.doi.org/10.4314/jab.v80i1.10

\begin{abstract}
:
Objectives: A survey of domestic small mammals and their associated fleas was conducted in Cotonou during the years 2008, 2009 and 2010. The objective of this study was to evaluate the potential role of small mammals in the transmission of anthropozoonosis.

Methodology and Results: A total of 1,402 domestic small mammals were captured in 54 stations using methods following Houémenou (2006). The most abundant small mammals were, Rattus rattus (black rat) (63.7\%), Mastomys sp. (multimammate rat) (11.84\%), Rattus norvegicus (brown rat) $(11.48 \%$ ) and Crocidura olivieri (7.85\%). Among these rodents, 364 individuals were found with ectoparasites, and 886 fleas were collected (flea index 0.63), the most common flea being Xenopsylla cheopis (rat flea) (97.2\%). This species was found in all areas of the city and infested all small mammal species. The Pulicidae prevalence $(26 \%)$ showed important variations, with relatively low and significantly higher prevalence during the rainy and dry seasons, respectively.

Conclusions and application of findings: Small mammal community in Cotonou was dominated by Rattus rattus and fleas by Xenopsylla cheopis. Due to the presence of a seaport of paramount importance, Cotonou town was not away from importation by sea transport of zoonotic rats (shelter ships calling at the port of Cotonou, from all continents). To date, in Cotonou there is lacking information on pathogenic agents hosted by the small mammals and their ectoparasites. Therefore, awareness of the authorities on the zoonotic risk of small mammals for the human population is necessary. The authorities of the Port Autonome de Cotonou must increase the screening of ships, which arrive at Cotonou to avoid zoonotic rodent importation. The Ministry of Human Health in Benin must sensitize the populations at high risk of the rodent transmitted diseases. Further studies are needed to detect the different animal reservoirs of these pathogenic agents.
\end{abstract}




\section{INTRODUCTION}

Urban population is growing faster in developing countries than in developed ones (UNDP, 2012). In African cities, urban rapid population growth usually exceeds national and local government capacity for the supply of basic services. This raises associated issues of poverty, unemployment, poor housing, poor or complete lack of sanitation (Firdaus, 2012). Rodents are among the most important reservoirs of zoonotic agents (Shoukry et al., 1991; Meersburg \& Kijlstra A, 2007 2009). As an example, Lassa fever, a viral hemorrhagic disease caused by the Lassa arena virus is maintained in the wild - and putatively transmitted to humans- by Mastomys natalensis (multimammate rat) (Bausch \& Rollin, 1997; Lecompte et al., 2006). Another famous illustration is rats and their role in the plague epidemiology, a disease that killed and still kills more people in the World that wars. (Birben, 1975; Bakr et al.,1996; Audouin-Rouzeau, 2002). Many cases of plague emergence worldwide was driven by the introduction of synanthropic rats (usually from the genus Rattus),

\section{MATERIAL AND METHODS}

Trapping of rodents was conducted following Houéménou (2006) from July to November 2008 and November 2009 to December 2010. The trapping stations were scattered throughout Cotonou and were grouped in two types of environment as:

- Uninhabited areas or none resident putative high risk areas: swamps

- urban environments with four habitat types according to resident population and the degree of sanitary along with their associated fleas (such as Xenopsylla cheopis in rats). The latter reservoir and vector species can both find acceptable conditions on ships. As such the role of transport, including sea transport, in their dissemination seems pivotal (Biraben, 1975). This makes many harbours across the World at risk from Yersinia pestis introduction. As such, Cotonou, main town of Benin, has an international seaport where ships from most continents land. From there, important roads connect Cotonou with the hinterland and surrounding countries such as Burkina Faso, Niger, Chad and Mali. Recently, a survey of small mammals conducted in urban and coastal environments of Benin by (Houéménou, 2006), showed the abundance of Rattus rattus (59.8\%), Mastomys sp. $(13.5 \%)$, and C. olivieri (8.6\%). The purpose of this article was to show results about their fleas as a preliminary step towards the assessment of the potential role of small mammals of Cotonou city in the transmission of anthropozoonoses.

infrastructure expressed in terms of potential risk of zoonoses.

- low risk: comfortable accommodations, modern health facilities often close to the sea;

- Moderate risk: basic sanitation, with latrines and sinks, open gutters. This was the centre of the core city; - $\quad$ high risk : no adequate health infrastructure, makeshift houses, "wild" dumps, along the lake and Cotonou channel to the shore of the sea;

- Markets and warehouses seaport of Cotonou. 


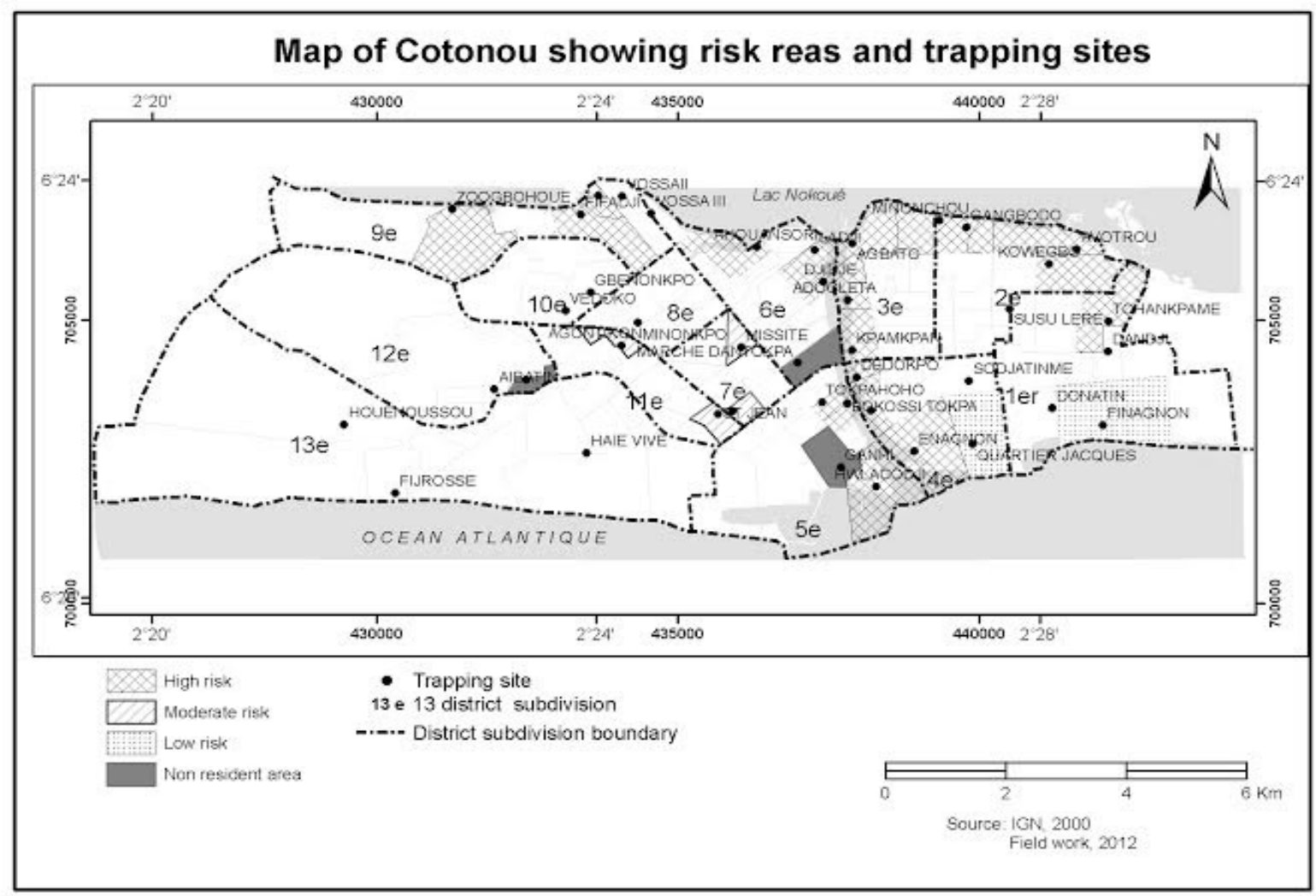

Fig 1: Map of Cotonou showing risk areas and trapping sites

Trapped rodents were anesthetized by placing those in iron bag containing cotton wool soaked with chloroform or ether. Taxonomic identifications were performed based on morphologic traits following De Visser et al. (2001). Ectoparasites killed during the rodent or shrew anaesthesia were collected from the bag with a flat forceps, while potentially remaining ones were sampled directly from the fur using a fine toothcomb over a sheet of white paper. These dislodged parasites from each rodent were pooled in collection tubes containing $70 \%$ alcohol and numbered in reference to their host. After dehydration in ethanol of increasing concentration, they were mounted between slide and cover slide using Eukitt (R) VWR 24065 or fixed within Hoyer's solution (Fain, 1984). Identification of flea was performed on morphologic grounds under a microscope (Ref Opt B151: 10 X 40) following Hopkins \& Rothschild (1953) and Beaucournu \& Launay (1990).

\section{RESULTS}

A total of 1,402 small mammals were captured in the 54 stations within Cotonou, with a total trapping effort of 8,340 trap-nights. Overall, the black rat $R$ attus rattus was dominant $(\mathrm{N}=893)$ with $63.7 \%$ of the whole sample.
Several indicators were then calculated:

- The prevalence was the ratio between the numbers of infected animals vs. the total number of captures.

- The flea index was the average number of flea hosted on a mammalian host species (specific index or for the whole community of infected mammals (General Index).

The sex ratio of flea-bearing animals was tested using the Z-score, while the sex ratio between infected and uninfected individuals was investigated through a $\chi 2$ test. For each host species, the prevalence of ectoparasites was compared between habitats and seasons (months) by a G-test (Goodness of fit test: Sokal \& Rolhf, 1981). The distributions frequency of the number of fleas per host species were compared by a nonparametric variance (Kruskal-Wallis) and Kolmogorov-Smirnov (D).

Mastomys sp. ( $\mathrm{N}=166 ; 11.84 \%)$, Rattus norvegicus $(\mathrm{N}=161 ; 11.48 \%)$, Crocidura olivieri $(\mathrm{N}=110 ; 7.85 \%)$ were much less common, while others were rare: Arvicanthis niloticus ( $N=4 ; 0.29 \%)$, Crocidura sp. $(\mathrm{N}=4 ; 0.29 \%)$, 
Cricetomys gambianus ( $\mathrm{N}=6 ; 0.43 \%)$, Mus domesticus $(\mathrm{N}=9 ; \quad 0.64 \%), \quad$ Gerbilliscus kempi $\quad(\mathrm{N}=11$; $0.78 \%)$,Taterillus gracilis ( $\mathrm{N}=14 ; 1 \%)$ and Dasymys rufulus $(\mathrm{N}=24 ; 1.71 \%)$ (Table 1). The black rat was widespread all over the city since it was present in 47 stations out of the $54(87 \%)$ with captures ranging from 1 to 74 (Table 2). Three other species also displayed a large distribution and were detected in more than half of the stations: Crocidura olivieri (65\%), Mastomys sp. $(63 \%)$, and Rattus norvegicus (52\%). Among these rodents and shrews, 364 individuals, representing all eleven species, were found to be parasitized by fleas, thus representing an overall prevalence of $26 \%$ (Table 1 ).

Table 1: Prevalence of flea (Siphonaptera) per animal host Tab 1: Prevalence of flea (Siphonaptera) per animal host

\begin{tabular}{|l|l|l|l|l|l|}
\hline Species & $\begin{array}{l}\text { number } \\
\text { of captures }\end{array}$ & $\begin{array}{l}\text { nb of animals } \\
\text { Hostt of flea }\end{array}$ & $\begin{array}{l}\text { specific } \\
\text { prevalence }\end{array}$ & $\begin{array}{l}\text { nb of } \\
\text { flea }\end{array}$ & nb of flea/animal host \\
\hline C. gambianus & 6 & 1 & 16.7 & 9 & 9 \\
C. olivieri & 110 & 25 & 22.7 & 62 & 2.48 \\
Mastomys sp. & 166 & 54 & 32.5 & 157 & 2.91 \\
R. norvegicus & 161 & 55 & 34.2 & 146 & 2.65 \\
R. rattus & 893 & 228 & 25.5 & 510 & 2.24 \\
T. gracilis & 14 & 1 & 7.1 & 2 & 2 \\
\hline Total & 1,350 & 364 & 27.0 & 886 & 2.43 \\
\hline
\end{tabular}

On the eleven species, only six were parasitized by fleas, with $R$. norvegicus being the most infested ( $\mathrm{N}=55$ infested individuals out of 364 examined; $34.2 \%$ ). Prevalence's in the five other species were as follows: $32.5 \%(\mathrm{~N}=54)$ in Mastomys sp., $25.5 \% \quad \mathrm{~N}=228$ ) in $R$. rattus , C. olivieri $22.7 \%$ (25), C. gambianus $16.7 \%$ (1) and T. gracilis $7.1 \%$ (1). Five species were not parasitized by fleas: $A$. niloticus, Crocidura sp., G. kempi, D. rufilus and Mus domesticus. Small differences in prevalence were observed: brown rats were more infested than other mammals (partial Gtest1ddl $=4.03, p<0.05$ ) (Table 1). The number of individuals parasitized by Pulicidae was relatively constant for the four most abundant small mammals ( $\mathrm{KW}=6.92 \mathrm{~ns}$ ). However, the frequency distribution of the number of fleas in Mastomys was significantly different from that observed in the other host species $(\mathrm{KS}: \mathrm{D}($ Crocidura $)=0.242 ; \mathrm{D}(R$. norvegicus $)=$ $0.195 ; \mathrm{D}$ (R. rattus) $=0.170 ; p \ll 0.01): 30 \%$ of Mastomys individuals hosted one flea, while half of the other mammal host did so (Fig. 2).

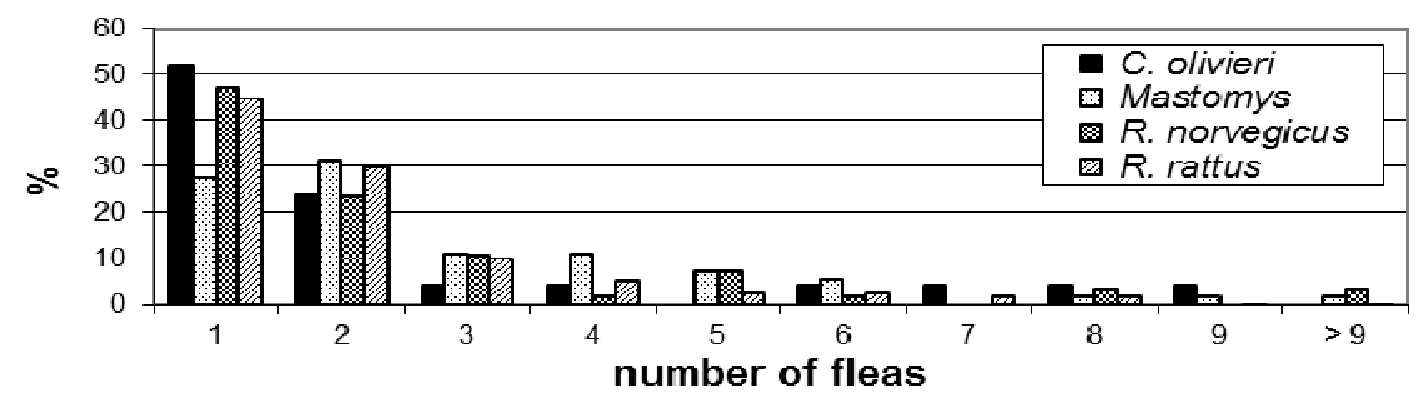

Fig. 2: Frequency distribution of number of flea per host

Animals infested by fleas were detected in 40 of the 54 stations $(74 \%)$. The highest percentages of infested animals were found in Midombo (56\%) and Ganhi (48\%), followed by Abokicodji (44\%) and (43\%).. Percentages 
Houmenou et al. J. Appl. Biosci. 2014. Spatiotemporal variations of the incidence of fleas (Siphonaptera) on domestic small mammals in Cotonou, Benin

were poorly informative in some sites where captures were too rare $(\mathrm{N}<11$ animals). In uninhabited areas, the prevalence of Siphonaptera was minimal $(1.3 \%)$. It was moderate $(12.5 \%)$ in low-risk ones, but was much more important in other areas like markets (32\%) (Table 2).

Table.2: Prevalence of Siphonaptera in different sitesper risk

\begin{tabular}{|l|ccc|cc|}
\hline & \multicolumn{3}{|c|}{ nb of animal host } & & \\
\hline Areas & 74 & 1 & 1.35 & G test partial ( ddl =1) & G test partial ( ddl = 1) \\
Low risk & 56 & 7 & 12.50 & 8.66 & $\mathrm{p}<0.001$ \\
Moderate risk & 300 & 83 & 27.67 & 0.59 & $\mathrm{~ns}$ \\
High risk & 849 & 236 & 27.80 & 1.35 & $\mathrm{~ns}$ \\
Markets & 116 & 37 & 31.90 & 1.98 & $\mathrm{~ns}$ \\
\hline
\end{tabular}

The overall flea index was 0.63 (886/1402), but the infestation was significantly greater in Mastomys and Rattus norvegicus $(p<0.005$,) while it was lower in $R$. rattus and $T$. gracilis. As far as specific diversity is concerned, the community was particularly poor: only three species of flea were identified: Xenopsylla cheopis, Xenopsylla brasiliensis and Ctenocephalides felis strongylus. $X$. cheopis $(\mathrm{N}=861)$ represents $97.3 \%$ of all fleas found. It infested black rats in 40 stations out of 54 , achieving the highest prevalence in the Abokicodji station of infested animals. Its main host, Rattus rattus, was present in 47 trapping sites, or all stations in the urban core environment. As such, the 40 sites where this flea was present were predominantly characterized by human settlements and the presence of garbage. Its presence would be strongly dependent on these two factors. Xenopsylla brasiliensis represents only $2.7 \%$ of all fleas $(\mathrm{N}=24)$ when $X$. cheopis $(\mathrm{N}=861)$ represents $97.3 \%$. According to Denwas et al. (1999), X. brasiliensis was the main flea in rural areas rather than urban centres. One cat flea, Ctenocephalides felis strongylus was collected on a Norway rat captured in Wlacodji. The frequency of infested mammals showed significant changes during the year

(Fig.3).

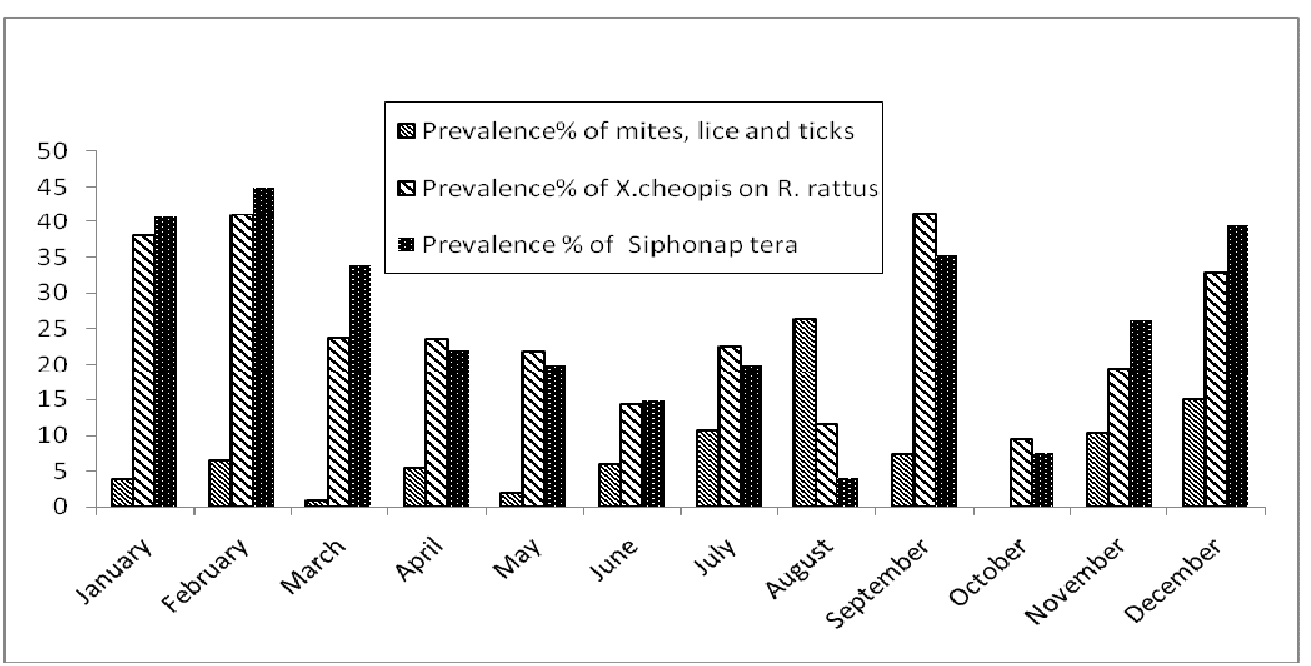

Fig 3: Monthly prevalence of mammalian ectoparasites in Cotonou

The prevalence of flea showed a peak in December, January and February and then decreased from March to June for back only in July, August and fall, shows a peak in September. In October, prevalence drops sharply and then rises again in November $(G=102.44 ; p \ll<0.001)$. 


\section{DISCUSSION}

Surveys of urban rodent diversity are quite scarce, especially in African cities (Garba, 2012). The capture of a large number of $R$. rattus was consistent with its wide distribution in the World (Vanasco et al., 2003; Wilson \& Reeder, 2005) and with its attested presence in other African cities like Alexandria and Cairo, Egypt (Morsy et al., 1988; Khalid et al., 1992), Harare, Zimbabwe (Zimba et al., 2011), Kinshasa, RDC (Laudsoit, 2004), Niamey, Niger (Garba, 2012) or Makurdi, Nigeria (Omudu \& Ati, 2010). This result is consistent with the hypothesis that the black rat is able to better adapt to tropical climatic and environmental conditions than the brown rat, $R$. norvegicus (Feng \& Himsworth, 2013). The relatively high number of Mastomys sp. and Crocidura spp. was supported by previous studies in Africa (Ratzooman, 2012). Several authors have sampled small mammals and their ectoparasites in different African cities, including Alexandria (Morsy et al., 1988), Cairo (Khalid et al., 1992.), Kinshasa (Laudisoit, 2004), Cotonou (Houémènou, 2006; this study), Makurdi (Omudu \& Ati, 2010) and Harare (Zimba et al., 2011). These authors calculated parasitic or Pulicidae prevalence as well as a series of indices: parasitic rate, flea index, among others. These results show a high variability between studies. The ectoparasitic prevalence varies between $10 \%$ (Morsy et al., 1988) to over $60 \%$ (Omudu \& Ati, 2010). In the same manner, the overall flea index varies from 0.08 (Omudu \& Ati, 2010) to 6.1 in urban peripheries of the upper valley of the Egyptian Nile (Maher et al., 1974). In Cotonou, the overall flea index was 0.63 , significantly more important than that of Kinshasa (0.28; Laudisoit, 2004 ) or in the city of Makurdi, Nigeria (0.08; Omudu \& Ati, 2010). In these cities, all small mammals, rodents and shrews, infested with fleas were hosts of Xenopsylla (Laudisoit, 2004; Omudu \& Ati, 2010; Zimba et al., 2011) like in this study (with the exception of the single cat flea). In addition, in all these case-studies, the Rattus rattus and Xenopsylla (cheopis and brasiliensis) combination seems constant: (Benin : this study; Congo: Laudisoit, 2004; Egypt: Maher Ali et al., 1974; Aboul Ela et al., 1987; Bakr et al., 1996; Khalid et al., 1992; Morsy et al.,

\section{ACKNOWLEDGMENTS}

We are grateful to the Government of Benin for the financial support of our study at University of Liege (Belgium). We thank all persons who helped made this study feasible, particularly those who have helped in the
1988; Nigeria, Omudu \& Ati., 2010; Zimbabwe, Zimba et al., 2011). This pattern shared between African cities may be extended further, for instance in Asia (India: Achutan \& Chandrahas, 1971; Philippines: Mercado, 1981). X. cheopis was considered urban flea by Beaucournu (1999). Our study in Cotonou is consistent with their suggestion. However, the global index of $X$. cheopis in Cotonou was relatively small, 0.60 per rat $(R$. rattus and $R$. norgevicus). This value appears much less than 5 , above which one considers that an outbreak of plague can occur (Aboul-Ela et al., 1987). The seasonal variation of flea abundance was assessed by different authors. In India, the prevalence of rat-borne $X$. cheopis from rural Kolar was maximum in August, September and October with a peak in August while it was minimal in April, May and June (Achutan \& Chandrahas, 1971). In the Cairo area, Khalid et al. (1992) and Bakr et al. (1996) found that the flea index was higher in spring but close to null in winter. In the Upper Nile region, Maher Ali et al. (1974) found a similar pattern in the suburban environment of cities and the cultivated areas (maximum in spring and minimum in autumn), whereas in semi-arid environments, the flea index falls from June until October. However, Laudisoit (2004) reported that in the tropics, the peak abundance of $X$. cheopis was observed during the coldest season. Closer to Benin, Ugbomoïko \& Obiamiwe (1991) found that, in Ekpoma (southern Nigeria), the seasonal rains positively influence adult fleas' abundance In Tanzania, in Lushoto District, Njunwa et al. (1989) recorded the highest flea index from December to May. A few years later in Lushoto district, Makundi (1999) reported that "the intensity of fleas (flea index) was highest in December / January and rapidly declined in April / May concomitantly with the peak of the rainy season. It was further observed that fleas were more abundant on rodent hosts when ambient temperatures were $22-26^{\circ} \mathrm{C}$ during November to April. Our results seem congruent with these findings. The lack of work on the subject in the sub-region of western Africa made the comparison of results difficult.

trapping and collection of rats: Florent Gnansounou, Honoré Houémènou, and Joel Dossou. We are also grateful to Dr Gauthier Dobigny for having read the manuscript and made his observations. 


\section{REFERENCES}

Aboul-Ela RG, Hilmy NM, El-Serafy SS, 1987. The seasonal variation of infestation rate with Xenopsylla cheopis among Rattus norvegicus in Qaluobiya governorate (Egypt). Journal of Egyptian Society of Parasitology 17: 125-133.

Achutan C \& Chandrahas KR, 1971. Seasonal prevalence of rat fleas in Kolar (Mysore State).Indian Journal of Medical Research 59 (6): 833-837.

Audouin-Rouzeau F, 2003. Les chemins de la peste. Le rat, la puce et l'homme. Edition Les PUR Rennes. $371 \mathrm{p}$.

Bakr EM, Morsy AT, Nassef AEN, El Meligi AM 1996. Fleas' ectoparasites of commensal rodents in Shebin El Kom, Menoufia Governorate, Egypt. Journal of Egyptian Society of Parasitology1: 39-52.

Bausch GD and Rollin EP, 1997.La fièvre de Lassa. Annales Institut Pasteur / actualités3: 223-231.

Beaucournu JC, 1999. Diversité des puces vectrices en fonction des foyers pesteux. Adresse URL. http//www.pasteur.fr/sante/scopatex/pdf/1999n5 b/Beaucou.pdf

Beaucournu JC and Launay H, 1990. Les Puces (Siphonaptères) de France et du Bassin méditerranéen occidental. Faune de France 76, Fédération française des sociétés de sciences naturelles. Biraben JN, 1975. Les hommes et la peste en France et dans les pays européens et méditerranéens. Vol. 1 : La peste dans l'histoire, 456 p. Vol.2 : Les hommes face à la peste. Mouton, Paris. $416 \mathrm{p}$.

De Visser J, Mensah GA, Codjia JTC, Bokonon-Ganta $\mathrm{AH}, 2001$. Guide préliminaire de reconnaissance des rongeurs du Bénin. ReREet VZZ, Cotonou, $252 p$.

Fain A, 1984. A new genus of mite (Acari: Acaridae) phoretic on bees (Ctenocolletes) in Australia. Records Western Australian Museum 11: 77-86.

FengTYA andHimsworth GC, 2013. The secret life of the city rat: a review of the ecology of urban Norway and black rats (Rattus norvegicus and Rattus rattus). Urban ecology.DOI 10.1007/s11252013-0305-4

Firdaus G, 2012. Urbanization, emerging slums and increasing health problems: a challenge before the nation: an empirical study with reference to state of Uttar Pradesh in India. Journal of Environment Research Management 9: 146152.
Garba M, 2012.Rongeurs urbains et invasion biologique dans le sud ouest du Niger : écologie des communautés et génétique des populations. Thèse de doctorat. Université Abdou Moumouni de Niamey. Niger. $261 \mathrm{p}$.

Hopkins GHE and Rothschild M, 1953. Illustrated catalogue of the Rothschild collection of flea (Siphonaptera) in the British Museum (Natural History).Vol I: Tungidae and Pulicidae. The trustees of the British Museum. London. $361 \mathrm{p}$.

Houémènou G, 2006. Première évaluation du rôle potentiel des micro-mammifères de la ville de Cotonou dans la transmission des anthropozoonoses. Mémoire de D.E.A. Université de Liège, $54 \mathrm{p}$.

Khalid LM, Morsy TA, el Shennawy SF, Farrag AM, Sabry AH, Mostafa HA,1992. Studies on flea fauna in El Fayoum Governorate, Egypt. Journal of the Egyptian Society of Parasitolology 3: 783799.

Laudisoit A, 2004. Les ectoparasites des petits mammifères de la ville de Kinshasa, République Démocratique du Congo : un facteur de risques pour la santé publique ? Mémoire de DEA en Biologie Animale. Unité Recherches Zoogéographiques, Université de Liège, $75 \mathrm{p}$.

Lecompte E, Fichet-Calvet E, Daffis S, Koulema K, Sylla $\mathrm{O}$, Kourouma F, 2006. Mastomys natalensis and Lassa fever, West Africa. Emerging Infectious Disease 12: 178-183.

Makundi RH, Oguge NO, Mwanjabe PS,. 1999.Rodent pest management in East Africa : an ecological approach. In :Ecologically-based rodent management. Eds Singleton GR, Hinds L, Leirs $H$, Zhang Z, pp. 460-476.

Meerburg BG and Kijlstra A, 2007. Role of rodents in transmission of Salmonella and Campylobacter Journal Science Food Agriculture 87: 27742781.

Mercado BS, 1981. Notes on ectoparasites of rats (Rattus norvegicus) inhabiting marketplaces in the city of Manila. Philosophy Journal Veterinary Medecine2: 67-71.

Morsy TA, Abou El-Ela RG, El Gozamy BMR, 1988.The commensal rodents and their flea fauna in Alexandria City. Egyptian Journal of Egyptian Society Parasitology 18: 11-28.

Njunwa KJ, Mwaiko GL, Kilonzo BS, Mhina JI, 1989. Seasonal patterns of rodents, fleas and plague status in the Western Usambara Mountains, 
Tanzania. Medical Veterinary Entomology 1: 1722.

Omudu EA and Ati TT, 2010.A survey of rats trapped in residential apartments and their ectoparasites in Makurdi, Nigeria. Research Journal of Agriculture and Biological Science2: 144-149.

RatZooMan.

http://www.nri.org/projects/ratzooman/publicatio ns.htm

Shoukry A, Merdan IA, El Khady AG, 1991. The role of rodents as reservoirs for some diseases in new reclaimed areas in north Sinai. Journal of Egyptian Society of Parasitology 2: 513-518.

Sokal R and Rohlf J, 1981. Biometry. 2nd ed. Freeman \& Co., New York, 859 p.

Ugbomoïko US and Obiamiwe BA, 1991. Distribution and incidence of ectoparasites on small mammals in a rainforest belt of southern Nigeria. Angew Parasitology 3: 143-148.
UNDP, 2012: United Nation Development Program 2012. Annual Report 2011/2012. The sustainable future we want. $34 \mathrm{p}$.

Vanasco NB, Sequeira MD, Sequeira G, Tarabla HD, 2003. Associations between leptospiral infection and seropositivity in rodents and environmental characteristics in Argentina. Preventive Veterinary Medicine 60: 227-235.

Wilson DE and Reeder DM (1993). Mammal species of the world. Washington. D.C. SmithsonianInstitution Press, $1207 \mathrm{p}$

Zimba M, Pfukenyi D, Loveridge J, Mukaratirwa S, 2011. Seasonal abundance of plague vector Xenopsylla brasiliensis from rodents captured in three habitat types of periurban suburbs of Harare, Zimbabwe. Vector Born Zoonotic Disease 8: 1187-1192. 